\title{
OBSADA BISKUPSTWA KRAKOWSKIEGO W LATACH I790-I9I4
}

„Ojcze święty i Panie najłaskawszy! Przedkładam Waszej Swiątobliwości moją i mego Królestwa pokorną prośbę. Wie o tym każdy, jak bardzo zależne jest powodzenie spraw publicznych i prywatnych od religii prawdziwiej i katolickiej. Nieskażoność zaś i wzrost religii jest tak wielce zależna od wielkich i czujnych biskupów. Waszej Świątobliwości jest też bardzo jasne jako najwyższemu sternikowi chrześcijańskiego świata i wszystkich kościołów, że pragnie mieć gorliwych współpracowników. Spodziewam się tedy, że będzie to nie małą radością dla gorliwości apostolskiej Waszej Świątobliwości, jeżeli na osieroconą stolicę biskupią w Krakowie wysuną takiego męża, który swoimi zasługami wobec Kościoła i państwa będzie w pełni odpowiadał wymogom i nadziei Waszej Świątobliwości i całego mojego Narodu". W takiej suplice polecał król Stanisław August Poniatowski w dniu 2 VI 1790 r. pap. Piusowi VI dotychczasowego biskupa łuckiego i brzeskiego Feliksa Pawła Turskiego na stolicę biskupią w Krakowie. W dalszej części tego listu postulacyjnego król polski stwierdzał, że wspomnianego kandydata ,,proponuje i prezentuje" i prosił papieża, by go raczył „zaaprobować” (comprobare) ${ }^{1}$. Była to ostatnia postulacja (a nie nominacja) króla polskiego w okresie niepodległej Rzeczypospolitej na biskupstwo w Krakowie.

Biskupstwo to zawakowało z chwilą śmierci biskupa Kajetana Ignacego Sołtyka († 20 VIII 1788); administratorem apostolskim diecezji był prymas Michał Jerzy Poniatowski ,dopóki inaczej nie zarządzi Stolica Swięta". Administracja miała trwać przeszło 2 lata. W międzyczasie diecezja na mocy konstytucji sejmowej z dnia 11 VI 1790 r. i brewe pa-

1 BAV (Bibliotheca Apostolica Vaticana) Processus consist. vol. 192 k. 102-125'. Processus R. D. Felicis Pauli Turski episcopi Luceoriensis transferendi ad ecclesiam cathedralem Cracoviensem - 1790 k. 103-103'. 
pieskiego Quum Reverendissimus z dnia 20 VII 1790 r. utraciła całe województwo lubelskie (7 dekanatów, łącznie 107 parafii i 7 filii) na rzecz diecezji chełmskiej ${ }^{2}$. Zgodnie $z$ postanowieniem konstytucji sejmowej z dnia 27 VII 1789 r. dobra biskupstwa wraz z Księstwem Siewierskim miały przejść na skarb państwa, a biskup krakowski miał otrzymać uposażenie $\mathrm{z}$ kasy państwowej z roczną pensją 100 tys. złp. ${ }^{3}$

Mimo tak poważnego uszczuplenia diecezji i konfiskaty olbrzymich posiadłaści mensy biskupiej, kandydatów na stolicę św. Stanisława nie brakło. Kandydował na nią sam prymas Poniatowski, ale nuncjusz apostolski Ferdynand Maria Saluzzo był przeciwny planom kumulacji w jednych rękach metropolii gnieźnieńskiej i prymasowstwa razem z biskupstwem krakowskim. Przeciwstawiał on prymasowi kandydaturę biskupa płockiego Krzysztofa Szembeka, podczas gdy Prusy popierały kandydaturę biskupa warmińskiego Ignacego Krasickiego ${ }^{4}$. O infułę krakowską czynił zabiegi na dworze królewskim w Warszawie biskup inflancki Józef Kossakowski przy pomocy wszechwładnego ambasadora rosyjskiego Stackelberga 5. Poważne perspektywy w tym zakresie miał mieć również reformator Akademii Krakowskiej i kanonik gremialny kapituły katedralnej w Krakowie, ks. Hugo Kołłątaj ${ }^{6}$. O biskupstwo krakowskie zwrócił się z bezpośrednią prośbą do króla Stanisława Augusta dziekan kapituły krakowskiej, ks. Michał Sołtyk ${ }^{7}$. Ale żaden z wymienionych kandydatów miał nie otrzymać Krakowa.

Podobno bez osobistych zabiegów kandydata, król Stanisław August zamianował $\mathrm{w}$ dniu 2 VI $1790 \mathrm{r}$. biskupem w Krakowie dotychczasowego biskupa łuckiego i brzeskiego Feliksa Pawła Turskiego; kapituła krakowska dokonała jego „wyboru” w dniu 12 VI t. r., a 27 VIII t. r. rozpoczą się jego proces informacyjny; w dniu 29 XI t. r. nastąpiła prekonizacja papieska, a nowy biskup w dniu 8 I 1791 r. przejął rządy w diecezji i w dniu 2 VI t. r. odbył uroczysty ingres do katedry św. Wacława na Wawelu. Po niecałych dziesięciu latach rządów biskup Turski zmarł w dniu 21 I 1800 r. ${ }^{8}$

2 B. Kumor, Granice metropolii i diecezji polskich (968-1939), Lublin 1969-1971, 218 (Nadb. z „Archiwa, Biblioteki i Muzea Kościelne”).

3 Volumina legum, T. 9. Kraków 1889, 104-105.

4 AKMK (Archiwum Kurii Metropolitalnej w Krakowie) Acta episcopalia, t. 117, s. 589-594; por. M. Pęckowski, Józef Olechowski archidiakon i sufragan krakowski 1735-1806, Kraków 1926, 135.

5 A. Zahorski, Kossakowski Józef Kazimierz, w: Pol. Słow. Biogr., t. 14, Wrocław 1968/69, 268-272; Z. Goliński, Krasicki Ignacy, Błażej Franciszek, w: Pol. Stow. Biogr., t. 15, Wrocław 1970, 144-150.

6 W. Tokarz, Ostatnie lata Hugona Kołłątaja 1797-1812, Kraków 1905, 202.

7 M. Pęckowski, dz. c., 135.

8 BAV Processus consist. vol. 192 k. 102; Hierarchia catholica medii et recentoris aevi, t. 6, Patavii 1958, 186; J. Korytkowski. Prałaci i kanonicy katedry metropolitalnej gniéźnieńskiej od roku 1000 aż do dni naszych, Gniezno 1883, t. 4, 152-156; MI. Pęckowski, dz. c., 144 nn. 
W chwili śmierci biskupa Turskiego Kraków od pięciu lat był pod zaborem austriackim. W dniu 7 IV t. r. kapituła wybrała na stanowisko wikariusza kapitulnego biskupa pomocniczego i archidiakona katedralnego Józefa Olechowskiego. Jego wybór po raz pierwszy potwierdzały rządowe władze austriackie ${ }^{9}$. Już po pierwszym rozbiorze cesarz austriacki przywłaszczył sobie prawo nominacji biskupów na ziemiach pierwszego zaboru, co po pewnym wahaniu i wątpliwościach uznała faktycznie Stolica Apostolska ${ }^{\mathbf{1 0}}$. Tym razem kiedy Państwo Polskie już nie istniało, sytuacja dla ces. Franciszka II była łatwiejsza. Zaraz po śmierci biskupa Turskiego władze austriackie przystąpiły do opracowywania projektów reorganizacji i uszczuplenia terytorium biskupstwa, a szereg kandydatów rozpoczęło zabiegi w Gubernium Zachodniej Galicji i w Wiedniu o infułę krakowską.

W dniu 13 VI 1800 r. gubernator Zachodniej Galicji J. hr. Trautmannsdorf stwierdzał, że „,cesarz jest zdecydowany, by nie tworzyć żadnego zastępczego tytułu książęcego dla przyszłego biskupa krakowskiego"; Księstwo Siewierskie bowiem zagarnęły w trzecim rozbiorze Prusy ${ }^{11}$. Faktycznie w dniu 5 IX 1803 r. cesarz ten zniósł tytuł książęcy biskupów krakowskich. Na żądanie centralnych władz austriackich Gubernium Galicji Zachodniej już w dniu 19 VII 1800 r. opracowało obszerny memoriał w sprawie reorganizacji i obsady diecezji krakowskiej 12. Mimo poważnych zabiegów kapituły krakowskiej diecezja została zacieśniona do 5 cyrkułów politycznych (Kraków, Olkusz, Bochnia, Wadowice, Nowy Sącz) i włączona do metropolii lwowskiej, a kapituła zredukowana do 3 prałatur i 4 kanonii gremialnych ${ }^{13}$.

Od początku rządów austriackich listę kandydatów na wakujące biskupstwa w Galicji sporządzało Gubernium Zachodniej Galicji i przesyłało ją wraz z własnymi uwagami do Nadwornej Komisji Duchownej w Wiedniu. Komisja ta ostateczną listę kandydatów wraz z własną opinią i gubernialną przesyłała cesarzowi. Ten zaś wybierał jednego z przedstawionych kandydatów i mianował go biskupem, po czym następowała publikacja nominacji i związane $\mathrm{z}$ nią akty kościelno-prawne: proces

9 AKapMK (Archiwum Kapituły Metropolitalnej w Krakowie) Acta actorum capituli ecclesiae cathedralis Cracoviensis 1793-1803 k. 584-594 (7 IV 1800); M. Pęckowski, dz. c., $172 \mathrm{n}$.

10 B. Kumor, Obsada metropolii lwowskiej obrzadku łacińskiego w latach 17801850, „Folia Societatis Scientiarum Lubinensis”, 18 (1976) Hum. 2, 98 n.

i1 "All. Verwal. Arch. (Allgemeines Verwaltungsarchiv. Wien.) Alte Kultus Akten. 33. Facs. 135. Bisthum Krakau. Nr 7 ex Junio $1800-$, wird bedeutet, dass S. Majestät entschlossen haben, dass es keines Surrogat für die einen künftigen Bischof von Krakau nich mehr gebührauche Titel eines Herzogs von Sewerien bediente"; por. B. Kumor, Granice, 300.

${ }_{12}$ All. Verwal. Arch. Alte Kultus Akten. 33. Fasc. 135. Bisthum Krakau J. W. Margelik do Nadwornej Kancelarii Cesarskiej w Wiedniu - 19 VII $1800 \mathrm{k}$. $1-46$ (oryg. w jęz. niem.).

13 B. Kumor, Granice, 305 n. 
informacyjny i prekonizacja papieska. Rzecz jasna, że rządy zaborcze zwracały uwagę na lojalną postawę polityczną kandydatów.

Nie znamy niestety odpowiednich list kandydatów na biskupstwo krakowskie, wystawione przez Gubernium Zachodniej Galicji, czy też przez Nadworną Komisję Duchowną. Przeprowadzona przez podpisanego bardzo szczegółowa kwerenda archiwalna w Wiedniu nie dała w tym zakresie żadnych rezultatów. Listę kandydatów znamy natomiast z relacji biskupa Ludwika Eętowskiego. Czy jest ona identyczna $\mathrm{z}$ listą gubernialną? Trudno dokładnie odpowiedzieć. Z późniejszych wypadków wiadomo, że niejednokrotnie przedostawały się do opinii publicznej nazwiska kandydatów, wystawianych na wakujące biskupstwa przez namiestnika Galicji. Według przekazu biskupa Łętowskiego o biskupstwo krakowskie zabiegali tym razem:

$1^{\circ} \mathrm{Ks}$. Andrzej Rawa Gawroński, prałat kanclerz kapituły krakowskiej, radca gubernialny, znający język niemiecki (ukończył studia wyżże w Wiedniu), popierany przez kanclerza Cesarstwa J. A. F. barona Thuguta ${ }^{14}$

$2^{\circ}$ Ks. Trzebiński, prałat kustosz kapituły krakowskiej, który „zachowanie miał u cesarzowej" i stanowił poważnego rywala dla ks. A. Gawrońskiego, ale zmarł jeszcze przed obsadą biskupstwa († 1804) ${ }^{15}$.

$3^{\circ}$ Ks. Michał Sołtyk, dziekan kapituły krakowskiej i archidiakon sandomierski; zabiegał on równocześnie o przywrócenie biskupstwu Księstwa Siewierskiego ${ }^{16}$.

$4^{\circ} \mathrm{Ks}$. Józef Olechowski, biskup pomocniczy i archidiakon krakowski, wikariusz kapitulny diecezji. Nakłoniony przez kapitułę wniósł prośbę do Gubernium, by „łaskawie między innymi raczyło go polecić Najświętszemu Majestatowi" (12 IV 1800). Prośbę jego poparła również kapituła krakowska (12 IV 1800) ${ }^{17}$.

„Smierć ks. Trzebińskiego pogodziła strony, bo o Sołtyku nie było mowy, a ks. Olechowski pewny biskupstwa źle stał u dworu" (bp L. Łętowski). Nominację na biskupstwo otrzymał od ces. Franciszka II „ze względu na gorliwość wykazaną w sprawach kościelnych i państwowych" w dniu 30 VIII 1803 r. ks. Andrzej Gawroński; dnia 4 V 1804 r. po długich sporach kompetencyjnych odbył się jego proces informacyjny, a w dniu 24 IX 1804 r. pap. Pius VII prekonizował go na Kraków. Po konsekracji, która odbyła się w Wiedniu, w dniu 5 V 1805 r. odbył

14 L. Łętowski, Katalog biskupów, prałatów i kanoników krakowskich, t. 2, Kraków 1853, 261 n.; M. Pęckowski, dz. c., 175; J. Poplatek, Gawroński Andrzej, w: Pol. Słow. Biogr., t. 7, Kraków 1948-1958, 323-324.

16 L. Eętowski, dz. c., 261; M. Pęckowski, dz. c., 175.

16 Tamże.

17 M. Pęckowski, dz. c., dodatki nr 10, s. 201 (Kapituła krakowska do Gubernium - 12 IV 1800), nr 11 s. 202 (Bp J. Olechowski do Gubernium - 12 IV 1800). 
uroczysty ingres do katedry na Wawelu i po 8 latach rządów diecezją zmarł w dniu 7 IV 1813 r. jako senator Księstwa Warszawskiego ${ }^{18}$. Był to jedyny biskup krakowski mianowany przed 1879 r. przez cesarza austriackiego.

Z chwilą śmierci biskupa Gawrońskiego Kraków należał jeszcze do Księstwa Warszawskiego. Wikariuszem kapitulnym został wybrany dziekan kapituły, ks. Michał Sołtyk, ale w dniu 18 XII 1813 r. zrezygnował z urzędu, a kapituła wybrała na jego miejsce biskupa kieleckiego Wojciecha Górskiego (18 XII 1813), który od 20 III 1815 r. rządził diecezją jako administrator apostolski 19.

$\mathrm{Na}$ kongresie wiedeńskim przy nowym podziale ziem polskich postanowiono, że diecezja krakowska będzie składała się z terytorium Wolnego Miasta Krakowa i poważnej części w Królestwie Polskim. Przy takim ukształtowaniu terytorium diecezji było jasnym, że cesarz austriacki musi zrezygnować z prawa prezenty i patronatu nad biskupstwem. Mocarstwa zaborcze zgodziły się na to, że prawa te przejmie cesarz rosyjski ,jako suwerenny władca Królestwa Polskiego w momencie kreowania Wolnej i Neutralnej Rzeczypospolitej Krakowskiej". Tak relacjonuje to zagadnienie dokument ces. Aleksandra I z dnia 30 IV 1815 r. Wprawdzie obydwaj świądkowie w procesie informacyjnym biskupa Woronicza stwierdzali tego samego roku, że ,nominacja jego nastąpiła za zgodą cesarza austriackiego i króla pruskiego", ale relacja ta jest błędna ${ }^{\mathbf{2 0}}$. Dokument bowiem nominacyjny ks. Jana Pawła Woronicza na biskupstwo krakowskie nie mówi nic na ten temat. Jest natomiast rzeczą zaskakującą, że nominacja ta została podpisana przez cesarza rosyjskiego w Wiedniu w dniu 30 kwietnia 1815 r., a więc przed formalnym podpisaniem dokumentów kongresu wiedeńskiego (3 V 1815). Późniejsza nieco konstytucja Królestwa Polskiego z dnia 27 XI 1815 r. mówiła, że „król mianuje arcybiskupów i biskupów różnych wyznań” 21, ale Stolica Apostolska prawa tego nigdy formalnie nie uznała, a to z tej przyczyny, że cesarz rosyjski był innego wyznania. Nie było bowiem wypadku, by papieże udzielali prawa nominacji na biskupstwa panującym niekatolikom.

18 BAV Processus consist. vol. 207 k. 192-207. Processus super promotione ad ecclesiam Cracoviensem R. D. Andreae Gawroński per Caesareo Regiam et Apostolicam Majestatem nominati - 1804 k. 199 (Kopia dokum. z 30 VIII 1803); Hierarchia catholica, t. 7, s. 166 (podaje datę nominacji na 12 XII 1803).

19 B. Kumor, Organizacja terytorialna diecezji kieleckiej, „Nasza Przeszłość”, 17 (1963) $211 \mathrm{n}$.

20 BAV Processus consist. vol. 211 k. 158-169. Processus R. D. Jaonnis Pauli Woronicz ad episcopatum Cracoviensem promovendi - - 1815 k. 167-167' Ayant trouvé l'evèche de Cracovie en vacant par la morte de son dernier evêque, et la droit de la nomination à cet evêche ayant élé attribué aux Empereurs de Russie comme souverains du Royaume de Pologne par les etipulations du Congrès relatives à la creation de l'Etat libre et neutre de Cracovie.

21 Konstytucje polskie 1791-1921, wyd. M. Handelsman, Warszawa 1922, 51. 
Nie wiemy natomiast czy w 1815 r. były inne kandydatury przedstawione ces. Aleksandrowi I. Bliski tych wypadków biskup Łętowski nic nie mówi na ten temat. Nominacja ks. Jana Pawła Woronicza miała miejsce 30 IV 1815 r.; w dniu 19 VI t. r. biskup pomocniczy kijowski Franciszek Remigiusz Zambrzycki przeprowadził na podstawie delegacji metropolity gnieźnieńskiego Ignacego Raczyńskiego proces informacyjny, a w dniu 31 XII 1815 r. pap. Pius VII bullą Apostolatus officium prekonizował ks. Woronicza na Kraków. W dniu 8 V 1816 r. odbyła się jego konsekracja w Warszawie, po czym przejął osobiście rządy $w$ diecezji krakowskiej 22. Warto' tu dodać, że papieska bulla prekonizacyjna nie wspomniała ani słowem o nominacji cesarskiej.

Po przeniesieniu biskupa J. P. Woronicza na metropolię warszawską (28 I 1828), kapituła krakowska wybrała wikariuszem kapitulnym ks. Karola Skórowskiego, dziekana tejże kapituły. Listę kandydatów na wakujące biskupstwo wysunął Senat Wolnego Miasta Krakowa; obejmowała ona dwa nazwiska:

$1^{\circ}$ Ks. Franciszka Zglenickiego, biskupa pomocniczego krakowskiego i archidiakona kapitulnego, oraz

$2^{\circ}$ Ks. Karola Skórowskiego, dziekana kapituły krakowskiej.

Zapytana przez wielkiego księcia Konstantego Rada Administracyjna Królestwa Polskiego wypowiedziała się za kandydaturą ks. Karola Skórowskiego (9 VIII 1829) ${ }^{23}$. Jego też zamianował ces. Mikołaj I biskupem krakowskim, a pap. Pius VIII prekonizował na biskupstwo krakowskie (27 VII 1829); konsekracja jego odbyła się w Warszawie w dniu 24 I 1830 r. ${ }^{24}$.

$\mathrm{Na}$ skutek zaangażowania się biskupa Skórowskiego po stronie powstania listopadowego władze carskie zabroniły mu spełniania jurysdykcji kościelnej nad częścią diecezji w Królestwie Polskim, a następnie wraz z Austrią wymogły na pap. Grzegorzu XVI, że ten w dniu $30 \mathrm{~V} 1835 \mathrm{r}$. polecił mu usunąć się $z$ Krakowa, chociaż zatrzymał nadal dlań tytuł i jurysdykcję biskupstwa krakowskiego. Wyjechał tedy do Opawy, gdzie zmarł w dniu 25 r 1851 r. ${ }^{25}$

Od czasu jego wyjazdu z Krakowa początkowo zarząd diecezji był rozảwojony. Częścią diecezji w Królestwie Polskim zarządzał od 15 VIII 1833 r. jako administrator apostolski ks. Adam Paszkowicz. Częścią die-

22 AKapMK, Prothocollon actorum capituli cathedralis Cracoviensis 1815-1824, 45-49; Hierarchia catholica, t. 7, 166 (podaje datę prekonizacji 18 XII 1815); L. Eętowski, Katalog, t. 2, 264-271.

${ }_{23}$ Sumariusz protokołów Rady Administracyjnej Królestwa Polskiego 1815-1867, Cz. 1, 1815-1830, t. 1, Warszawa 1958, nr 804, s. 333.

24 BAV Processus consist. vol. $288 \mathrm{k} .146-153$. Processus R. D. Caroli Skórkowski decani cathedralis Cracoviensis in episcopatum eiusdem Ecclesiae promovendi - - 1829; L. Eętowski, Katalog, t. 7, 271-174.

25 Tamże; Hierarchia catholica, t. 7, 166. 
cezji w Wolnym Mieście Krakowie zarządzał jako wikariusz i oficjał generalny biskupa Skórkowskiego, biskup pomocniczy z Krakowa Franciszek Zglenicki. Z dniem 24 XI 1835 r. zjednoczył on w swoich rękach obydwie części diecezji, ale na podstawie różnych tytułów prawnych; w Królestwie Polskim rządził jako wikariusz apostolski, zaś w Wolnym Mieście Krakowie jako wikariusz i oficjał generalny biskupa Skórkowskiego. Podobny charakter w obydwu częściach diecezji miały rządy biskupa pomocniczego (od 1844), ks. Ludwika Eętowskiego w latach 1841 1848. Po jego rezygnacji w dniu 22 VI 1848 r. z obydwu urzędów, biskup Skórkowski zamianował wikariuszem i oficjałem generalnym na Wolne Miasto Kraków ks. Mateusza Gładyszewicza (10 II 1849) część diecezji w Królestwie Polskim otrzymała osobnego wikariusza apostolskiego w osobie ks. Macieja Majerczaka (24 V $1848 \pm 21$ IV 1849). Odtąd rozdwojenie zarządu diecezją przybrało charakter stały ${ }^{26}$.

Ale takie rozwiązanie nie zadowoliło rządów zaborczych, które obawiając się wciąż wielkiego wpływu biskupa Skórkowskiego na rządy kościelne w diecezji, jeszcze pod koniec 1847 r. (17 XII) planowały jego przeniesienie z Opawy do Klagenfurtu, względnie do Gurk ${ }^{27}$. Zresztą sy-tuacja polityczna sprzyjała działaniu Rosji i Austrii na szkodę dla jedności diecezji. W 1846 r. Kraków został wcielony do Austrii i w tym samym czasie kanclerz rosyjski Nesselrode w związku z pertraktacjami Rosji o konkordat ze Stolicą Apostolską oświadczył, że Rosja podtrzymuje nadal uchwały konferencji mocarstw zaborczych w Cieplicach, dotyczące podziału diecezji krakowskiej 28 .

W tej sytuacji rząd austriacki postanowił zmienić formę rządów kościelnych w Krakowie (od 20 XII 1849) i zaczął zabiegać w Rzymie o mianowanie ks. M. Gładyszewicza wikariuszem apostolskim dla austriackiej części diecezji. Pertraktacje szły jednak ciężko i przeciągnęły się do początków 1851 r., a to ze względu na stanowisko zajęte przez pap. Piusa IX, który nadal uważał biskupa Skórkowskiego za ordynariusza krakowskiego i respektował jego akty prawne w diecezji ${ }^{29}$. Jest pewnym, że rząd wiedeński rzeczywiście w 1849 r. rozważał możliwość obsadzenia biskupstwa krakowskiego, mimo że jego ordynariusz żył wciąż na wygnaniu w Opawie. Swiadczą o tym dwa dokumenty rządu austriackiego z 1849 r. w tej sprawie. Niestety obydwu dokumentów brak jest w odpowiednim fascykule w Haus-Hof-und Staatsarchiv w Wiedniu. Zostały

26 B. Kumor, Granice, 306-307.

27 HHSt. F. 26. Generalia 1830-1860. Fasc. 8 k. 49-50 (Wniosek kanclerza Deheima z 17 XII 1847), 72-73 (Nota rosyjska w sprawie biskupa Skórkowskiego 23 VI 1847), 74-75 (Nota kanclerza Nesselrodego z 8 VI 1846).

¿s Tamże. Fasc. 26 Generalia. S. V. 1861-1869 (Pismo kanclerza Nesselrodego do kanclerza austriackiego Deheima z 1846 r.).

29 B. Kumor, Granice, 308. 
one po prostu przez kogoś zabrane, a zachowały się jedynie ich streszczenia w protokolarzu kancelarii Rady Państwa ${ }^{30}$.

Problem obsady Krakowa własnym ordynariuszem nawet po śmierci biskupa Skórkowskiego nie był prosty, a to głównie z tytułu podwójnej przynależności politycznej diecezji. Wprawdzie sama stolica diecezji, Kraków był od 1846 r. pod panowaniem Austrii, ale większa część terytorium diecezji była pod panowaniem Rosji. Nie były też unormowane nie tylko sprawy terytorialne i gospodarcze biskupstwa, ale również i patronackie. Od 1815 r. carowie rosyjscy faktycznie mianowali biskupów w Krakowie. Teraz zaś, odkąd Kraków dostał się ponownie pod panowanie Austrii, było to niemożliwe, by mianowany przez cesarza austriackiego biskup krakowski, mógł zarządzać diecezją w Królestwie Polskim.

Pewne wyjście z impasu spowodowała śmierć biskupa Skórkowskiego (1851). W dniu 5 II 1851 r. kapituła krakowska wybrała wikariuszem kapitulnym ks. M. Gładyszewicza ${ }^{31}$, co potwierdził nuncjusz wiedeński (14 II) i ces. Franciszek Józef I (23 III 1851) ${ }^{32}$. Rządy jego obejmowały tylko tereny austriackiej części diecezji, w granicach dawnego Wolnego Miasta Krakowa i trwały do 28 V 1862 r., kiedy to ks. Gładyszewicz zmarł.

Smierć dotychczasowego wikariusza kapitulnego i wybór przez kapitułę jego następcy w osobie ks. Karola Teligi, kustosza kapitulnego (30 V 1862) ${ }^{33}$, nielubianego przez reakcyjny rząd Bacha i oskarżonego o filopolskie nastawienie, postawiły znów na porządku dziennym sprawę reorganizacji diecezji. W dniu 27 VI 1862 r. cesarz na wniosek rządu polecił wszcząć w Rzymie starania o usunięcie ks. Teligi od rządów kościelnych w Krakowie i nominację na wikariusza apostolskiego dziekana kapituły tarnowskiej, ks. Antoniego Gałeckiego; w dniu 3 VII 1862 r. władze wiedeńskie przekazały sprawę do załatwienia ambasadzie austriackiej w Rzymie ${ }^{34}$. Tymczasem kard. Antonelli, jako sekretarz stanu pap. Piusa IX, w rozmowie $\mathrm{z}$ ambasadorem austriackim Bachem oświadczył:

$1^{\circ}$ że spełnienie postulatów Austrii „,jest dla Stolicy Swiętej bardzo trudne, albo wprost niemożliwe";

$2^{\circ}$ usunięcie wikariusza kapitulnego mogłoby nastąpić tylko w wypadku niekanonicznego wyboru, albo też jego osobistych win moralnych, lub niekościelnej postawy;

30 HHSt. 4 St. R. Protocoll 1849 nr 1512 i 1549.

31 AKMK Acta administratorialia dioecesis Cracoviensis 1841-1859, 90-93 (Dokument wyboru ks. M. Gładyszewicza - 5 II 1851). 220.

32. HHSt. Cabinettsakten $1851 \mathrm{nr} 967$; por. B. Kumor, Organizacja terytorialna,

33 AKapMK Acta actorum capituli Cracoviensis, vol. 30 s. 32-34.

34 HHSt. F. 28. Generalia. G. Diözesen 1861-1869. Fasc. 23: Diözese Krakau. Akten von 1839-1863 (Min. spr. zagr. do ambasady austriackiej w Rzymie 3 VIII 1862). 
$3^{\circ}$ na sugestię ambasadora, że już w 1846 r. powstała myśl separacji diecezji zgodnie z politycznymi granicami, kard. Antonelli oświadczył, że „rząd austriacki we własnym interesie powinien przeprowadzić reorganizację diecezji, oraz zapewnić jej pełne utrzymanie praw jurysdykcyjnych i gospodarczych w Królestwie Polskim, a wreszcie zaproponować na jej stolicę odpowiedniego kandydata ${ }^{35}$. Wobec takiej postawy Stolicy Apostolskiej Austria postanowiła wybrać kompromis; w Rzymie kontynuowała starania o nominację ks. Gałeckiego na wikariusza apostolskiego w Krakowie, a Rosji zaproponowała rozmowy na temat nowej cyrkumskrypcji diecezji krakowskiej. Wówczas i pap. Pius IX zmienił postawę i bullą Apostolatus officium z dnia 25 IX 1862 r. zamianował ks. Gałeckiego biskupem tytularnym i wikariuszem apostolskim dla austriackiej części diecezji ${ }^{36}$. Uposażenie wikariusza apostolskiego miały stanowić dochody dziekanii kapitulnej w Tarnowie, kustodii krakowskiej i dodatek z funduszu religijnego. Rządy ks. Gałeckiego w Krakowie miały trwać do 1879 r. ${ }^{37}$.

Od 1860 r. Austria prowadziła z Rosją rozmowy na temat podziału diecezji krakowskiej, zakończone dopiero w 1874 r. Dnia 21 VI 1874 r. podpisano protokół końcowy, złożony z 21 artykułów. Z ważniejszych warunków protokołu można wymienić:

$1^{\circ}$ obydwa rządy zgodziły się na podział diecezji krakowskiej zgodnie $\mathrm{z}$ istniejącymi granicami politycznymi;

$2^{\circ}$ rząd austriacki uznał pretensje Rosji do sumy 930897 rubli z tytułu uposażenia konsystorza kieleckiego za lata 1848-1874, oraz do spłacenia Rosji dalszych 235018 rubli;

$3^{\circ}$ rząd austriacki $\mathrm{w}$ imieniu dưchowieństwa krakowskiego przyjął od Rosji 1149529 rubli tytułem odszkodowania za jego dobra położone w granicach Królestwa Polskiego ${ }^{38}$. Odtąd obydwa mocarstwa prowadziły niezależnie od siebie pertraktacje ze Stolicą Apostolską na temat reorganizacji diecezji krakowskiej (Austria) i utworzenia diecezji kieleckiej (Rosja).

Obszerny memoriał z dnia 9 VI 1878 r., opracowany przez namiestnika Galicji, hr. A. Potockiego proponował zarówno powiększenie terytorialne diecezji i ustalenie nowego uposażenia dla niej, jak też i postulował przejęcie praw patronackich i nominacyjnych w stosunku do biskupstwa kra-

35 B. Kumor, Granice, 308.

36 Tamże; L. Łętowski, Wspomnienia pamiętnikarskie, Wyd. H. Barycz, Wrocław 1952, 229-232; T. Glemma, Gałecki Junosza Antoni, w: Pol. Słow. Biogr., t. 7, Kraków 1848-1958, 240-241; S. Dobrzanowski, Biskup Antoni Gałecki wikariusz apostolski krakowski, w: Studia $z$ historii Kościoła w Polsce, t. 1, Warszawa 1972. $30-41$.

37 HHSt. 15 K. Z. $1863 \mathrm{nr} 3303 / 63$ z 14 X 1863.

38 B. Kumor, Granice, 309. 
kowskiego przez cesarza austriackiego, co rzeczywiście zawarował sobie ces. Franciszek Józef I dla siebie i swoich następców (22 IX 1878), a co potwierdził pap. Leon XIII w bulli Sanctae Apostolicae Sedis z dnia 20 I 1880 r. ${ }^{39}$ Jeszcze w 1876 r. dzienniki lwowskie wysunęły przypuszczenie, że po usunięciu z Krakowa niepopularnego wikariusza apostolskiego ks. Antoniego Gałeckiego, jeden z członków kapituły metropolitalnej lwowskiej zostanie powołany na stanowisko administratora diecezji krakowskiej. Ponieważ wiadomości te powtarzały się, dlatego kapituła krakowska na posiedzeniu w dniu $17 \mathrm{~V} 1876 \mathrm{r}$. w celu zapobieżenia takiemu obrotowi rzeczy, uchwaliła specjalne memorandum i przesłała je na adres namiestnictwa we Lwowie. W memoriale tym stanęła ona w obronie przysługujących jej praw do wyboru wikariusza kapitulnego na wypadek wakansu stolicy biskupiej w Krakowie ${ }^{40}$.

W Galicji po 1850 r. zgodnie z konkordatem austriackim z 1855 r. oraz patentem ces. Franciszka Józefa I z dnia 7 V 1874 r. cesarzowi przysługiwało prawo prezenty i nominacji biskupów. Przepisy prawne wymagały od kandydata obywatelstwa austriackiego, odpowiedniej postawy morainej i obywatelskiej, oraz odpowiednich zdolności do piastowania urzędu kościelnego. Kandydatów na stolice biskupie w Galicji wysuwało namiestnictwo we Lwowie, które jednak zasięgało opinii w tym zakresie od łacińskich ordynariuszów galicyjskich. Ostateczną listę kandydatów formował sam namiestnik i wraz z opiniami personalnymi kandydatów przesyłał ją do Wiednia. Dalej sprawy prowadziło Ministerstwo Wyznań Religijnych i Oświecenia Publicznego. Na jego to prośbę Ministerstwo spraw zagranicznych zwracało się do nuncjatury papieskiej w Wiedniu z zapytaniem, czy kandydat będzie acceptabilis dla Stolicy Apostolskiej. W wypadku pozytywnej odpowiedzi cesarz dokonywał nominacji kandydata, ale nominacja ta miała charakter ściśle tajny. Powiadomione o fakcie nominacji Ministerstwo Spraw Zagranicznych zwracało się teraz pisemnie do nuncjatury papieskiej w tej sprawie, a po pozytywnej odpowiedzi pisemnej nuncjatury, Ministerstwo Spraw Zagranicznych przesyłało nominację ambasadzie austriackiej przy Watykanie. Po telegraficznej odpowiedzi z Rzymu, że kandydat otrzyma prekonizację papieską, następowała publikacja nominacji, przeprowadzenie procesu informacyjnego, prekonizacja papieska i przesłanie bull papieskich nominatowi za pośrednictwem ambasady austriackiej przy Watykanie. W ciągu trzech miesięcy po prekonizacji, zgodnie z przepisami Soboru Trydenckiego (Sess. XXIII cap. 2) winna się odbyć konsekracja kandydata, jeżeli nie miał sakry biskupiej. Z chwilą prekonizacji biskupa papież w każdym wypadku wy-

39 Tamże, 310 .

40 AKapMK Acta actorum Capituli cathedr. Cracoviensis 1875-1898, $83 \mathrm{n}$. 
syłał do cesarza bullę specjalną, zaczynającą się z reguły od słów Gratiae divinae proemium ${ }^{41}$.

Tak też w zasadzie odbywał się proces nominacji i prekonizacji biskupów krakowskich od 1879 r. Przypatrzmy się bliżej tym nominacjom, głównie na podstawie bogatych materiałów archiwalnych z Wiednia i częściowo z Krakowa.

Zgodnie z najwyższym postanowieniem ces. Franciszka Józefa I z dnia 22 IX 1879 r. namiestnik Galicji, hr. A. Potocki po zasięgnięciu opinii metropolity lwowskiego Franciszka Wierzchlejskiego opracował listę kandydatów na biskupstwo krakowskie i przesłał je do Wiednia. Zdaje się, że w tej sprawie nie zasięgnął informacji biskupa tarnowskiego J. A. Pukalskiego i przemyskiego M. Hirschlera. Nie wspomina nic o tym jego pismo skierowane $\mathrm{w}$ tej sprawie do Wiednia. W oparciu o to pismo Mi.. nisterstwo WR i OP złożyło wniosek do ces. Franciszka Józefa I w dniu 19 IV 1879 r. i zaproponowało za namiestnikiem trzy kandydatury na Kraków:

$1^{\circ} \mathrm{Na}$ pierwszym miejscu znalazł się ks. Albin Dunajewski, prałat pa-pieski, kapłan archidiecezji lwowskiej i kapelan Sióstr Wizytek w Krakokie. To pierwsze miejsce wśród pozostałych kandydatów dał mu zarówno metropolita lwowski Franciszek Wierzchlejski, jak też i namiestnik hr. A. Potocki, oraz Ministerstwo WR i OP we wniosku do cesarza. Podkreślano jego nieprzeciętne zdolności, pracowitość, czystość obyczajów, wzorową postawę i mir jakim się cieszył wśród duchowieństwa krakowskiego. Nie pominięto jednak i tego, że kandydat był za sprawę narodową w więzieniu austriackim. Przy końcu pisma nie omieszkał namiestnik zaakcentować specjalnej prośby, by Ministerstwo WR i OP przeprowadziło jego właśnie nominację.

2 Na drugim miejscu postawiono kandydaturę ks. Józefa Sebastiana Pelczara, profesora historii Kościoła i prawa kanonicznego na Wydziale Teologicznym Uniwersytetu Jagiellońskiego.

$3^{\circ} \mathrm{Na}$ trzecim miejscu widniało na liście kandydatów nazwisko ks. Ludwika Bobera, katechety gimnazjalnego w Krakowie, a następnie proboszcza w Chrzanowie ${ }^{42}$.

$\mathrm{Na}$ liście kandydatów zabrakło osoby wikariusza apostolskiego z Krakowa, biskupa Antoniego Gałeckiego, który z chwilą nominacji ks. Dunajewskiego, opuścił Kraków incognito (po 26 IV 1879) i udał się do Wiednia, gdzie zmarł 10 III 1885 r. Ale lista kandydatów nie obejmowała również popieranego przez prezydenta miasta Krakowa M. Zyblikiewicza, biskupa

41 HHSt. P. A. XI. Interna. Liasse LX. Úbliche Vorgangsweise bei der Ausübung des Präsentationsrechtes Seines $K$. und K. Apostolische Majestät.

42 HHSt 8. K. Z. $1879 \mathrm{nr}$ 1622, Vortrag des Cultusminister von 19 IV 1879 
pomocniczego poznańskiego Jana Janiszewskiego, który od kilku lat mieszkał w Krakowie jako wygnaniec i ofiara kulturkampfu ${ }^{43}$.

Kandydaturę ks. Dunajewskiego poparł w Rzymie wpływowy ks. Włodzimierz Czacki i zmartwychwstańcy z ks. P. Semeneńką na czele. To też po 28 latach faktycznego wakansu biskupstwa w Krakowie ces. Franciszek Józef I w dniu 21 IV 1879 r. zamianował biskupem krakowskim ks. Albina Dunajewskiego. Jeszcze w kwietniu tegoż roku przeprowadzono proces informacyjny, a pap. Leon XIII bullą Apostolatus officium z dnia 15 V 1879 r. prekonizował go na Kraków. Tego samego dnia wystawiono dalsze bulle dla nominata, do cesarza, do metropolity warszawskiego, jako że diecezja krakowska w latach 1818-1880 była jego sufraganią i do kapituły i wiernych w diecezji krakowskiej ${ }^{44}$.

W dniu 8 VI 1879 r. konsekracji biskupiej udzielił ks. Dunajewskiemu nuncjusz papieski Ludwik Jacobini przy udziale biskupa gr. kat. Jana Stupnickiego i biskupa polowego Antoniego Gruschy. W 1880 r. pap. Leon XIII powiększył diecezję o 101 parafii i 329345 wiernych, ces. Franciszek Józef I patentem z dnia 19 I 1889 r. przywrócił biskupom krakowskim tytuł książęcy, a pap. Leon XIII w dniu 23 VI 1890 r. kreował ks. Dunajewskiego kardynałem prezbiterem tytułu ss. Gerwazego i Protazego ${ }^{45}$. Po wielu zmiennych kolejach losu diecezja krakowska stabilizowała swoje terytorium i zajęła znów jedno z pierwszych miejsc w hierarchii Kościoła polskiego.

Po śmierci kard. A. Dunajewskiego ( $\div 18$ VI 1894) kapituła krakowska pod przewodnictwem dziekana ks. J. K. del Campio Scipio wybrała w dniu 23 VI 1894 r. wikariuszem kapitulnym ks. Feliksa Gawrońskiego, kustosza kapitulnego, co potwierdził cesarz dekretem z dnia 20 VII 1894 r. ${ }^{46}$ Według relacji pamiętnikarskiej ks. J. S. Pelczara, namiestnik Galicji hr. Kazimierz Badeni (1846-1909) „myślał zrazu o wyniesieniu mnie (ks. J. S. Pelczara) na opróżnioną stolicę, ale później przedstawił cesarzowi o. Henryka Jackowskiego" ${ }^{47}$. Ten sam autor $w$ liście $z$ dnia 22 VIII 1894 r. pisał na ten temat, że „co do stolicy krakowskiej - p. Badeni z pewną partią Stańczyków chciał na nią wynieść o. Jackowskiego, ale mądry jezuita oparł się stanowczo i uderzył aż do cesarza, do którego

43 S. Dobrzanowski, Restauracja diecezji krakowskiej w latach osiemdziesiatych XIX wieku, Warszawa 1970 (maszynopis) 79; Z. Grot, Janiszewski Jan Chryzostom, w: Pol. Słow. Biogr., t. 10, Wrocław 1962-1964, 523-524; J. S. Pelczar. Wybór pism. Wyd. M. Kras, „Nasza Przeszłość”, 29 (1968) 93.

44 HHSt. Geistliche Agentie-Akten 159 (1879 - Dunajewski. Kopie bull papieskich i inne pisma).

${ }_{45}$ T. Glemma, M. Tyrowicz, Dunajewski Albin, w: Pol. Stow. Biogr., t. 5, Kraków 1939-1946, 262-264; S. Dobrzanowski, dz. c., $105 \mathrm{nn}, 192 \mathrm{nn}$.

46 HHSt. 14 K. Z. 1894 Nr 3331/94; AKapMK T. 34. Acta actorum capituli Ecclesiae cathedralis Cracoviensis 1875-1898 k. nie paginowane (pod data 23 VI 1894); A. Schletz, Gawroński Hilary Feliks, w: Pol. Słow. Biogr., t. 7. Kraków 1947-1957. $351-352$.

47 J. S. Pelczar, dz. c., 112. 
też napisał ich generał. Mimo to 14 sierpnia powołał minister Madejski ojca Jackowskiego do Krakowa na jakąś konferencję. Co więcej p. Badeni na przedstawienie jezuitów, że o. Jackowski jest już styrany na siłach i chory, miał powiedzieć, że mu da sufragana" ${ }^{48}$.

K to i kim był o. Henryk Jackowski i jak przedstawia się sprawa obsady biskupstwa w Krakowie w świetle archiwaliów wiedeńskich? Ks. H. Jackowski urodził się 8 VIII 1834 r. w rodzinie ziemiańskiej w Jabłowie $\mathrm{w}$ diecezji chełmińskiej. Po studiach średnich w Braniewie i Gdańsku i czteroletnich studiach prawniczych na Uniwersytecie Berlińskim, studiował teologię w Rzymie na Uniwersytecie Gregoriańskim, a następnie w Pelplinie, gdzie też w dniu 3 IV 1860 r. przyjął święcenia kapłańskie z rąk biskupa J. N. Marwicza, którego był krewnym. Jako kapłan diecezji chełmińskiej był ekspozytem w Bytowie (1860/61), a następnie został powołany przez metropolitę warszawskiego Melchiora Fijałkowskiego na profesora teologii moralnej w Akademii Duchownej w Warszawie i mianowany kanonikiem honorowym kapituły łowickiej. Zrezygnował jednak z tych propozycji i 31 XII 1861 r. wstąpił do jezuitów w Starej Wsi koło Brzozowa. W latach $1864-1870$ był misjonarzem w Śremie w Wielkopolsce, w latach 1871-1877 rektorem i mistrzem nowicjatu w Starej Wsi. Od 1879 r. pracowal przebrany za kupca wśród unitów na Podlasiu, a zdradzony przez 18 miesięcy przebywał w więzieniu carskim w Siedlcach, gdzie dalej tajnie pełnił akcję misyjną. Po opuszczeniu więzienia został rektorem kolegium jezuickiego w Krakowie, w latach 1881-1887 był prowincjałem, a następnie superiorem we Lwowie i Krakowie.

$\mathrm{Na}$ tych stanowiskach rozwinął on nadzwyczaj aktywną działalność. $\mathrm{Na}$ polecenie pap. Leona XIII zreformował unicki zakon bazylianów w Galicji, założył kilka nowych domów i kolegium jezuickie w Chyrowie. Za jego czasów zaczęły wychodzić redagowane przez jezuitów „Misje katolickie”, „Przegląd powszechny”, „Intencje Apostolstwa”. Sam pisa1 i wydawał bardzo dużo, głównie z zakresu ascetyki. Był jedną z najwybitniejszych postaści wśród kleru galicyjskiego $(\dagger 1905)^{49}$.

Według urzędowych dokumentów wiedeńskich sprawy nominacji ks. H. Jackowskiego TJ na Kraków przedstawiały się następująco. W archiwum kancelarii cesarstwa nie zachował się wniosek pisemny Ministerstwa WR i OP w sprawie jego nominacji, chociaż w każdym innym wypadku taki wniosek zachował się. Na pewno był $\mathrm{w}$ tej sprawie wniosek namiestnika Galicji hr. K. Badeniego, przesłany do ministra WR i OP St. Z. Madejskiego († 1910) zapewne pod koniec czerwca, lub też na po-

48 Tamże, 160.

49 „Nasze Wiadomości”, 1 (1905) nr 6 (nekrolog); por. M. B., Jackowski Henryk, w: Podr. Encykl. Kośc., t. 17/18, Warszawa 1909, 251-253. Wojtoń Wł., ś.p. O. Henryk Jackowski. „Gazeta Kośc.”, R. 13 (1905) 167-170, 181-182. 
czątku lipca 1894 r. Lista namiestnika zawierała tylko jedną kandydaturę, o. H. Jackowskiego TJ. Namiestnik zatem nie zasięgał opinii episkopatu galicyjskiego w tej sprawie, zrobił to dopiero później. Kandydaturę o. Jackowskiego omówił ustnie minister Madejski z ces. Franciszkiem Józefem I w czasie jego odpoczynku w Ischlu w Austrii Górnej. Cesarz kandydaturę zaaprobował, w następstwie czego rozpoczęły się poufne rozmowy na ten temat ze Stolicą Apostolską za pośrednictwem nuncjatury wiedeńskiej i z generałem jezuitów w Rzymie (przed 18 VII 1894).

Generał jezuitów Ludwik Martini w liście z dnia 18 VII 1894 r., skierowanym bezpośrednio do ces. Franciszka Józefa I, chcąc uprzedzić poufną odpowiedź sekretariatu stanu, kard. M. Rampolli, pisał m. in. „Moja pokorna, natarczywa prośba idzie w tym kierunku, by Wasz Cesarski i Królewski Majestat skłonił się do tego, by w wyborze kandydata na stolicę arcybiskupią (sic!) w Krakowie nie brał pod uwagę ani żadnego innego z członków naszego Towarzystwa, ale inną osobę, która byłaby godna tak wysokiego urzędu" 50. W uzasadnieniu takiego stanowiska ks. L. Martini TJ powoływał się na regułę i konstytucje jezuitów, które zgodnie z przepisami św. Ignacego Loyoli stanowczo żądały, by członkowie Towarzystwa nie przyjmowali w żadnym wypadku wyższych godności kościelnych i zobowiązywał ich do tego specjalnym ślubem. Mogli to uczynic tylko na wyraźny nakaz papieża. „,Tej cennej zasady — stwierdza generał Martini - Towarzystwo strzegło święcie od śmierci Założyciela aż do ostatnich dni i zdecydowanie opierało się wynoszeniu swoich członków do godności kościelnych z wyjątkiem wyraźnego nakazu papieża, a taki był tylko w wypadku nadawania godności kardynalskiej". Jezuiccy biskupi misyjni mają z tytułu swego urzędu, ,więcej pracy, niż honorów, a jeszcze mniej dochodów", a kardynałowie pracują w kurii papieskiej w Rzymie. W dalszych partiach przedługiego listu - supliki pisał generał Martini, że od przeszło 300 lat istnienia Towarzystwa Jezusowego żaden z jego członków nie był biskupem w Europie, mimo że ces. Ferdynand I zabiegał w XVI w. o biskupstwo w Trydencie dla jezuity P. Le Laya, a dla ks. P. Kanizego o biskupstwo w Wiedniu. Nominacja jezuity na biskupa przyniosłaby tylko ,zamiast zbudowania - zgorszenie wielu”.

Odnośnie osoby o. H. Jackowskiego generał Martini zaakcentował jego słabe zdrowie, zniszczone niezwykłą pracowitością. „Można spodziewać się — pisał dalej — uzasadnionej reakcji dworu carskiego w Petersburgu, że nominacja o. Jackowskiego nie będzie tam przychylnie przyjęta. Kraków bowiem jest w oczach Rosji centrum propagandy wśród Rusinów unitów, a sam o. Jackowski jest mężem zbyt dobrze z tej strony znanym

50 HHSt. 14 K. Z. 1894 Nr 3124/894 (Ludwik Martini TJ do ces. Franciszka Józefa I - 18 VII 1894. oryg. w języku niem.). 
rządowi rosyjskiemu, jako że działał wśród Rusinów w Królestwie Polskim i swoją gorliwość odpokutował długotrwałym więzieniem".

Te długie wywody generał Martini kończył „natarczywą prośbą, by cesarz przy wyborze i nominacji kandydatów na stolicę biskupią w Krakowie nie brał pod uwagę żadnego z członków Towarzystwa Jezusowego, a tym bardziej by nie przedstawiał ich kandydatur w formie „,natarczywej” Stolicy Apostolskiej”. Spodziewał się też, że „cesarz chce, by Towarzystwo trwało w prawdziwej i pełnej pomyślności", stąd jeszcze raz „natarczywie prosił” i zaklinał cesarza, by ,zachował Towarzystwo od takiego nieszczęścia". ${ }^{51}$

Sprawa nominacji jezuity Jackowskiego komplikowała się nie tylko na skutek takiego stanowiska generała zakonu, ale napotykała na dodatkowe trudności ze strony Stolicy Apostolskiej. Zgodnie z obowiązująca procedurą jeszcze przed publikacją nominacji władze rządowe zapytywały poufnie za pośrednictwem nuncjatury wiedeńskiej Stolicę Apostolską. Według ustnej relacji nuncjusza wiedeńskiego Aghliardi ,,papież uważa, że nominacji jezuity Jackowskiego na biskupa w Krakowie stają na przeszkodzie tego rodzaju trudności, że mogą one Stolicy Swiętej przysporzyć wiele kłopotów, a tych lepiej unikać w sprawach publicznych". Stąd też - miał oświadczyć papież — biorąc pod uwagę zdecydowany opór generała zakonu jezuitów, ,z przykrością musi przyjąć sam rezygnację Ojca Jackowskiego z tej kandydatury i ustnie to przekazać ministrowi Jego Cesarskiej Mości”. Tę też wiadomość przesłał minister Madejski cesarzowi, bawiącemu nadal w Ischlu (28 VII 1894), a ten w dniu 31 VII t. r. przyjął ją do wiadomości 52.

To stanowisko Stolicy Apostolskiej i generała jezuitów zadecydowało, że władze rządowe postanowiły ustąpić. Wyrazem tego był list ces. Franciszka Józefa I do generała jezuitów Martiniego z dnia 5 VIII $1894 \mathrm{r}$. W liście tym pisał cesarz m. in. „Pismo, skierowane do Nas w sprawie obsady książęco-biskupiej stolicy w Krakowie, znalazło u mnie pełne zrozumienie. Przytoczone w nim uzasadnione trudności przeciw powołaniu o. Henryka Jackowskiego na stolicę biskupią, skłoniły mię ostatecznie do całkowitej rezygnacji z tej kandydatury. W tym przekonaniu zostałem utwierdzony przez otrzymaną ostatnio wiadomość, że również Jego Świątobliwość papież zaakcentował podobne trudności”. Nie omieszkał jednakże cesarz dodać, że „nie może jednak ukryć swego bólu, że okoliczności nie pozwoliły tego dzielnego i godnego zaufania kapłana postawić na takim stanowisku, na którym mógłby rozwinąć bogatą działalność

51 Tamże - Vortrag des Cultus minister Ritter von Madeyski dd. 28 VIII $1894 \mathrm{nr} 1436 / \mathrm{C}$. U. M. vomit im Vervolge seiner an mundlichen Darlegungen in Ischl an zur All. Kenntniss gebracht wird.

${ }_{52}$ Tamże nr 3524/94. Entwurf einer Allerhöchsten Handbittes an den General der Jesuiten-Orden Ludwig Martini in Fiesole - 5 VIII 1894 (or. w języku niem.). 
w interesie Kościoła i państwa" ${ }^{53}$. Zapewne ta decyzja cesarska została zakomunikowana o. Jackowskiemu w dniu 14 VIII t. r. w Krakowie przez ministra Madejskiego ${ }^{54}$.

Dopiero teraz namiestnik Galicji hr. K. Badeni zwrócił się do episkopatu galicyjskiego ob. łac. w sprawie przedstawienia ewentualnych kandydatów na stolicę biskupią w Krakowie. W tej sprawie wypowiedzieli się na piśmie wszyscy trzej biskupi ze Lwowa, Przemyśla i Tarnowa.

Metropolita lwowski ob. łac. Seweryn Morawski wysunął następujące kandydatury:

$1^{\circ}$ Ks. Jan kniaź Puzyna, biskup pomocniczy i wikariusz generalny, oraz kanonik metropolitalny we Lwowie.

$2^{\circ}$ Ks. Feliks Gawroński, wikariusz kapitulny i kustosz kapituły krakowskiej.

$3^{\circ}$ Ks. Józef Sebastian Pelczar, kanonik kapituły krakowskiej i profesor Uniwersytetu Jagiellońskiego.

$4^{\circ} \mathrm{Ks}$. Władysław Chotkowski, profesor Uniwersytetu Jagiellońskiego, poseł do Rady Państwa i prałat papieski ${ }^{55}$.

W świetle tego dokumentu okazuje się, że relacja ks. J. S. Pelczara na ten temat nie jest dokładna. Jeżeli metropolita S. Morawski „chciałby koniecznie zatrzymać ks. bpa Puzynę i wniósł podobno prośbę o mianowanie go koadiutorem cum iure successionis", to w żadnym wypadku nie wystawiałby jego kandydatury na pierwszym miejscu na Kraków. Zresztą już wówczas, kiedy tę relację pisał ks. Pelczar (3 XI 1894), biskup Puzyna był już zamianowany ordynariuszem krakowskim ( 7 X 1894). Nie sprawdza się również podejrzenie, że metropolita lwowski „na przedstawienie jego (ks. Pelczara) kandydatury - na biskupa pomocniczego we Lwowie - przez ministra Madejskiego, odpowiedział negative" 56. Zapewne gdyby żywił uprzedzenie do osoby ks. J. S. Pelczara, to nie wysuwałby jego kandydatury na Kraków.

Drugą listę kandydatów dostarczył biskup tarnowski Ignacy Łobos. Obejmowała ona 3 nazwiska:

$1^{\circ}$ biskup Jan Puzyna,

$2^{\circ}$ ks. J. S. Pelczar,

$3^{\circ}$ ks. Władysław Chotkowski ${ }^{57}$.

Godne jest uwagi wysunięcie na stolicę biskupią w Krakowie kandydatury ks. Władysława Chotkowskiego. Był to Wielkopolanin, powstaniec

53 Tamże.

54 J. S. Pelczar, dz. c., 160.

55 HHSt. $18 \mathrm{~K}$. Z. $1894 \mathrm{Nr}$ 4462/94 Vertrag Ministeriums für Cultus und Unterricht - Ritter von Madeyski dd. 2 X 1894.

56 J. S. Pelczar, dz. c., $161 \mathrm{n}$.

57 Zob. przyp. nr 55. 
z 1863 r., kapłan poznański i ofiara kulturkampfu. Pozbawiony w 1873 r. przez rządy pruskie stanowisk kościelnych, otrzymał w 1882 r. katedrę historii Kościoła na Uniwersytecie Jagiellońskim, mimo że jeszcze wówczas nie posiadał obywatelstwa austriackiego. W latach 1891/92 był rektorem tegoż Uniwersytetu. Znany był jako płomienny kaznodzieja i redaktor „Przyjaciela Ludu” 58 .

Bardziej obfita w kandydatury była lista biskupa przemyskiego Łukasza Soleckiego, obejmowała ona nazwiska 3 biskupów i 3 księży:

$1^{\circ}$ biskup tarnowski Ignacy Łobos,

$2^{\circ}$ biskup pomocniczy przemyski Jakub Glazer,

$3^{\circ}$ biskup pomocniczy lwowski Jan Puzyna,

$4^{\circ}$ ks. Feliks Zabłocki, dziekan kapituły metropolitalnej we Lwowie,

$5^{\circ}$ ks. Józef Sebastian Pelczar kanonik kapituły krakowskiej,

$6^{\circ}$ ks. Teofil Łękawski kanonik kapituły przemyskiej ${ }^{59}$.

We wszystkich trzech listach nazwisko biskupa pomocniczego we Lwowie, ks. Jaana Puzyny powtarzało się, dwukrotnie na pierwszym, a raz na trzecim miejscu. Tylko raz powtórzyło się nazwisko biskupa tarnowskiego Ignacego Łobosa.

Decydujące jednak znaczenie miała posiadać lista kandydatów i opinia namiestnika Galicji hr. K. Badeniego. Ten wprawdzie we wniosku przekazanym Ministerstwu WR i OP w Wiedniu podał listy kandydatów, wytypowanych przez episkopat galicyjski, ale na pierwszym miejscu umieścił biskupa pomocniczego lwowskiego Jana Puzynę i jego nade wszystko zalecał na wakujące stanowisko biskupa krakowskiego. We wniosku zwracał uwagę, że ,stolica biskupia w Krakowie ma nadzwyczajne znaczenie" ${ }^{60}$. Podkreślał też bardzo mocno, że „,najchętniej widziałby na tej stolicy superiora jezuitów ze Lwowa o. Henryka Jackowskiego", ale w tej sytuacji, gdy jest to niemożliwe był zdania, że „jedyną osobistością po o. Henryku Jackowskim, którą można polecić na stolicę książęco-biskupią 'w Krakowie jest biskup pomocniczy lwowski Jan Puzyna". Po dołączeniu szczegółowych jego personaliów, namiestnik Badeni dodawał, że „ma on liczne zalety ducha i serca, z których dał się poznac zarówno na polu działalności państwowej i kościelnej, oraz że jest sumiennym i na wysokim poziomie $\mathrm{w}$ wypełnianiu obowiązków swego powołania kapłańskiego. Dał się też poznać jako książę Kościoła o nastawieniu pojednawczym i pokojowym. Jego - nadzwyczaj skuteczna i owocna działalność, w której wykazał wiele taktu, inicjatywy i spraw-

${ }_{58}$ T. Glemma, Chotkowski Władysław Longin, w: Pol. Słow. Biogr., t. 3, Kraków 1937, 430-432.

59 Zob. przyp. nr 55.

${ }_{60}$ Tamże - Der Stathalters für Galizien weitts auf die ausserordentliche Bedeutung, welche der fürstbischöfliche Stuhl in Krakau besitzt hin. 

ności organizacyjnej, zjednały mu wśród duchowieństwa i w kręgach świeckich powszechne uznanie i szczery szacunek"'.

Wniosek namiestnika Badeniego trafił do rąk ministra WR i OP Madejskiego, ten zaś po konsultacji z ministrem Galicji Apolinarym Jakubem Jaworskim, znanym $\mathrm{z}$ zachowawczego stanowiska ${ }^{61}$, w dniu $6 \mathrm{X}$ 1894 r. skierował prośbę do ces. Franciszka Józefa I o mianowanie go ordynariuszem krakowskim. W dniu 1 X t. r. kandydatura biskupa Puzyny została przedstawiona i przyjęta na posiedzeniu Rady Państwa.

Po takich zaleceniach było prawie pewnym, że tym razem nominacja biskupa Puzyny na Kraków dojdzie do skutku. Zresztą nie zdarzyło się po 1860 r., by zalecany przez namiestnika Galicji kandydat na biskupstwo nie otrzymał go z nominacji cesarskiej. I w tym wypadku nie było inaczej. W dniu 7 X 1894 r. cesarz zamianował biskupa Puzynę księciembiskupem w Krakowie ${ }^{62}$. Jeszcze w tym samym roku nurcjatura wiedeńska przeprowadziła proces informacyjny, w dniu 22 I 1895 r. pap. Leon XIII dokonał jego prekonizacji, a 17 II 1895 r. nastąpił ingres do katedry św. Wacława na Wewelu ${ }^{63}$. W dniu 15 IV 1901 r. pap. Leon XIII kreowal go kardynałem, a w dniu 25 IV t. r. w Budapeszcie ces. Franciszek Józef I nałożył mu biret kardynalski ${ }^{64}$. Zmarł w dniu 8 IX 1911 r., sekretarz kapituły zanotował ,prawdziwy mąż Boży, odnowiciel bazyliki katedralnej, twórca Małego Seminarium Duchownego i reorganizator Wyższego Seminarium Duchownego" 65.

W dniu 14 IX 1911 r. kapituła katedralna zebrana na posiedzeniu nadzwyczajnym w liczbie 9 członków (nieobecny był ks. W. Chotkowski - chory) pod przewodnictwem dziekana kapituły ks. Feliksa Gawrońskiego wybrała wikariuszem kapitulnym biskupa pomocniczego Anatola Nowaka, prałata scholastyka kapituły krakowskiej; jego wybór w dniu 6 XI t. r. cesarz przyjął do wiadomości ${ }^{66}$.

Tym razem namiestnikiem Galicji był głośny historyk Michał Bobrzyński († 1935); on też w swoich pamiętnikach przekazał szczegółowe informacje na temat obsady biskupstwa krakowskiego w 1911 r. Zapytany w tej sprawie episkopat galicyjski ob. łac. podał kandydatury różnych

${ }_{61}$ J. Buszko, Jaworski Apolinary Jakub, w: Pol. Słow. Biogr., t. 11, Kraków $1964 / 65,104-105$.

62 HHSt. 18 K. Z. $1894 \mathrm{nr}$ 4462/94 - Ich ernenne den Weihbischof und Generalwikar der röm. kath. Erzdiözese Lemberg Dr. Johann Ritter von Puzyna zum Fürstbischofe von Krakau - Gödöllo 7 X 1894.

63 HHSt. Geistliche Agentie-Akten. Fasc. 2041895 (Kopie bull papieskich. korespondencja biskupa Puzyny $\mathrm{z}$ ambasadą austriacka przy Watykanie); Notificationes - - 1895, s. 1-5; AKapMK Acta actorum Illustrissimi Capituli Ecclesiae Cathedralis Cracoviensis 1875-1898, bez paginacji (pod data 17 II 1895).

${ }_{64}$ HHSt. F. 26. Kardinäle (1870-1918) $\mathrm{Nr} 1 / 11-14,2 / 1-18$ (Korespondencja związana z nominacją na kardynała).

${ }_{65}$ AKapMK Acta actorum Illustrissimi Capituli Ecclesiae Cathedralis Cracoviensis ab anno 1906-1927, bez paginacji (pod data 8 IX 1911).

66 Tamże (pod datą 14 IX 1911); HHSt. K. Z. $1911 \mathrm{nr} 3215$. 
osobistości. $\mathrm{Na}$ pierwszym miejscu wymieniano biskupa pomocniczego w Krakowie Anatola Nowaka, który pełnił równocześnie urząd wikariusza kapitulnego. Ale namiestnik Bobrzyński w stosunku do tej kandydatury wniósł zastrzeżenia. Stwierdzał, że ,jego osoba nie może być brana pod uwagę przy obsadzie książęco-biskupiej stolicy w Krakowie ze względu na istniejące bardzo specyficzne okoliczności i samotny styl życia kandydata; książę biskup krakowski bowiem w daleko szerszym zakresie niż inni biskupi diecezjalni w Galicji musi mieć kontakty z kręgami najwyższej inteligencji i ziemiaństwa" ${ }^{67}$. Kandydatura biskupa Nowaka cieszyła się natomiast szczególnym poparciem metropolity lwowskiego Józefa Bilczewskiego.

Innych kandydatur poza biskupem A. Nowakiem i ks. A. S. Sapiehac imiennie nie wymienia wniosek ministerialny, ale według współczesnych relacji drugim kandydatem wysuniętym przez episkopat galicyjski był biskup pomocniczy lwowski, Władysław Bandurski, ,posiadający zaufanie zbliżonego do krakowskich konserwatystów ks. kardynała Puzyny, choć sam nie podzielał jego politycznych poglądów i zbliżał się do patriotycznej i demokratycznej „Nowej Reformy”. Ten wybitny kaznodzieja i działacz polityczny na rzecz obrony Chełmszczyzny, nie został wymieniony we wniosku namiestnika Bobrzyńskiego ${ }^{68}$. Faktem jest natomiast, że jego kandydaturę wysunął na drugim miejscu ksiądz biskup przemyski J. S. Pelczar 69.

$\mathrm{Na}$ trzecim miejscu wysunął metropolita lwowski J. Bilczewski kandydaturę biskupa przemyskiego J. S. Pelczara, co zresztą nieznanymi kanałami dostało się najpierw do wiedeńskiej „Reichspost”, a następnie do "Gazety Narodowej". W związku z tym pisał biskup Pelczar do metropo-lity Bilczewskiego w dniu 20 X 1911 r. m. in. „to atoli jest przykrym, że ktoś może nie bez oburzenia myśleć, jakoby rząd w porozumieniu z Jego Eminencją Ks. Metropolita postawił na trzecim miejscu starszego biskupa, a Stolica Swięta kandydaturę jego odrzuciła, dlatego, że on nie jest księciem ani hrabią. To przypuszczenie, acz nieuzasadnione, wywołałoby niezdrowe wrażenie, a nawet zaszkodziłoby ks. Sapieże; też dobrze by było, gdyby księża i świeccy zwłaszcza w diecezji krakowskiej wiedzieli, że o stolicę krakowską wcale się nie ubiegam i że dlatego kandydatury mojej nikt nie stawiał ani odrzucał. Nie żądam atoli formalnego sprostowa-

67 HHSt. K. Z. Nr 3232 (1911 - Bischofs) Nowak's hebt der Statthalter hervor, dass er denselben deshalb für den erledigten fürstbischöflichen Stuhl nicht geeignet hatte, die derselbe aus sehr bescheidenen Verhältnissen hervorgegangen ein zurückgezogenes Leben führe, der Fürstbischof von Krakau jedoch — höherenen Masse als jeder anderen galizische Diözesanbischof genötigt sei mit den höchsten Schichten der Intelligenz und Adels Beziehungen zu unterhalten.

${ }_{68}$ P. Zółtowski, Wspomnienia o kardynale Adamie Stefanie Sapieże z okazji 60-lecia ingresu na krakowska stolice biskupia, „Nasza Przeszłość”, 37 (1972) 224; Bandurski Władysław, Pol. Słow. Biogr., t. 1., Kraków 1935, 263-264. 
nia w „Gazecie Narodowej” i zdaję się zupełnie na sąd Waszej Ekscelencji" 70. Trzeba jednak dodać, że tym razem kandydatura biskupa Pelczara nie znalazła się we wniosku ministerialnym.

Na drugim miejscu biskup Pelczar podał na liście do namiestnictwa biskupa pomocniczego przemyskiego Józefa Fischera, na trzecim zaś biskupa pomocniczego lwowskiego Władysława Bandurskiego, jako że „tych dwóch trudno pominąć" ${ }^{71}$. Ale żaden z nich nie znalazł się na liście ministerialnej. Nie znamy natomiast listy kandydatów, wysuniętych przez biskupa tarnowskiego Leona Wałęgę. Skądinąd wiadomo, że na liście proponowanej przez episkopat był „kanonik Potulicki z Ołomuńca" 72. Czyżby to był kandydat biskupa Wałęgi?

Jest faktem, że kandydaturę ks. Adama Stefana Sapiehy (1867-1951), kanonika kapituły metropolitalnej we Lwowie, wysunął jeden z biskupów galicyjskich. Nie jest wykluczone, że jego kandydaturę wysunął biskup Wałęga z Tarnowa; po nim bowiem ks. A. S. Sapieha otrzymał kanonię lwowską w 1902 r., a w latach późniejszych biskup Wałęga należał do głównych inicjatorów utworzenia metropolii kościelnej w Krakowie. Zdaje się, że kandydaturę ks. Sapiehy mógł wysunąć na dalszym miejscu metropolita Bilczewski ${ }^{73}$. Na jego bowiem opinię powoływał się wniosek Ministerstwa WR i OP w sprawie mianowania ks. Sapiehy biskupem krakowskim. Kandydaturę tę poparł „chociaż z wahaniem” namiestnik Bobrzyński. Oto co sam pisze na ten temat: Kandydaturze tej „był arcybiskup przeciwny, wolał bowiem na stolicy krakowskiej widzieć ks. Anatola Nowaka, biskupa sufragana i uległ dopiero mojej perswazji, gdym mu przedstawił, iż jest rzeczą pożyteczną, ażeby także arystokracja polska miała w episkopacie galicyjskim swego przedstawiciela. Uległszy, zachował jednak z tegoż tytułu do mnie urazę i objawił mi ją zaraz przy ingresie nowego biskupa w Krakowie, na którym wojsko (bez mojej ingerencji) wystąpiło publicznie i utworzyło biskupowi szpaler od pałacu do katedry, co przy innych ingresach było praktykowane. Odezwał się wówczas do mnie ks. Bilczewski: „aleś to Ekscelencja Sapieże urządził ingres wspaniały, nawet z wojskiem" ${ }^{74}$. We wniosku do Ministerstwa WR i OP namiestnik Bobrzyński zaznaczył, że ,arcybiskup Bilczewski scharakteryzował księcia Sapiehę jako bardzo gorliwego kapłana, prowadzącego życie bez skazy, który jako członek kapituły metropolitalnej i radca konsystorski miał okazję do zdobycia doświadczenia i wiedzy po-

69 J. S. Pelczar, dz. c., 192.

70 Tamże, 194.

7 Tamże, 192 .

72 P. Żątowski, dz. cy., 224.

${ }_{73}$ Zob. przyp. 67 - Unter den von der Diözesanbischöfen genannten Kandidaten glaubt der Statthalter eigen sich nur der Domherr Fürst Sapieha für den fürstbischöfliche Stuhl in Krakau.

${ }^{\prime}$ M. Bobrzyński, Z moich pamiętników, Wrocław 1957, $370 \mathrm{n}$. 
trzebnej do rządzenia diecezją, oraz że posiada on zaufanie Ojca świętego" 75 .

Około kandydatury ks. Sapiehy zabiegał w Wiedniu minister Galicji Wacław Zaleski, a popierał ją marszałek S. M. Badeni, ,ażeby ród Sapiehów frondujący dotychczas politycznie uspokoić". Udzielając sam poparcia kandydaturze ks. Sapiehy na Kraków namiestnik Bobrzyński „obawiał się, żeby drugi syn ks. Adama, zostawszy biskupem krakowskim, nie wstąpił również $\mathrm{w}$ te ślady. $\mathrm{Z}$ drugiej strony mówiłem sobie, że długoletni pobyt ks. Adama na dworze papieskim nie minął przecież bez wielkiego wrażenia na nim i bez rozszerzenia jego horyzontu poza granice ciasnych rywalizacji. Udałem się dlatego do kilku najwybitniejszych konserwatystów krakowskich, a w szczególności do obu Tarnowskich i przedstawiwszy im całą rzecz, zapytałem o zdanie jak mam postąpić. Oświadczyli się za tą kandydaturą, a ja korzystając z przybycia ks. Sapiehy na pogrzeb kard. Puzyny zaprosiłem go do siebie i oświadczając gotowość zaproponowania go na biskupstwo, przedstawiłem mu wszystkie moje kłopoty, jakie mam $z$ jednej strony wskutek nieprzejednanego stanowiska wobec ludowców biskupa Wałęgi, a z drugiej strony wskutek licytowania Stapińskiego $\mathrm{w}$ radykaliźmie przy reformie wyborczej przez pisma katolickie, redagowane przez księży. Wyraziłem oczekiwanie, że ks. Sapieha, rozejrzawszy się $\mathrm{w}$ położeniu, pomoże mi do ułagodzenia tych stosunków. Przyjął to bardzo życzliwie, a konserwatyści krakowscy, zwłaszcza obaj Tarnowscy, oczekując tego samego co ja, nowego biskupa w Krakowie przyjęli najserdeczniej. Zawiedli się na tym wkrótce i poparcia jego kandydatury gorzko żałowali. W biskupie Sapieże zwyciężyła tradycja ojców i wpływ brata Pawła i pałac biskupi krakowski stał się wkrótce ogniskiem, w którym skupiły się żywioły centrum i podszywając się pod katolicyzm żywioły narodowo-demokratyczne, rozsadzające stronnictwo konserwatywne krakowskie" 76 .

Nie bez znaczenia $\mathrm{w}$ przyjęciu tej kadydatury był wzgląd na stanowisko pap. Piusa X, przy którego boku od 1906 r. pracował ks. Sapieha jako jego rzeczywisty tajny szambelan. Na zapytanie metropolity Bilczewskiego „czy prawdą jest, że Ojciec święty o nominację Sapiehy napisał list do cesarza”, namiestnik Bobrzyński odpowiedział — „nic o tym nie wiem”, ale dodał od siebie, ,gdybym jednak nie był Sapiehy proponował na biskupstwo krakowskie, przypuszczam, iż nie jest rzeczą wy-

75 Zob. przyp. 67 - Erzbischof Bilczewski bezeichnet den Fürsten Sapieha als ein tüchtigen Priester von mackellosen Lebenswandel, welcher als Mitglied des Domkapitels und als Konsistorialrath Gelegenheit hatte, Kentnisse und Erfahrungen in der Leitung der Diözese zu sammeln, und das Vertrauen S. Heiligkeit besitze.

${ }_{76}$ M. Bobrzyński, dz. c., 371 n. 
kluczoną, iż Ojciec Święty byłby poruszył kandydaturę ks. Sapiehy, jako swego przez szereg lat szambelana" 77 .

Uzgodniona kandydatura ks. Sapiehy na Kraków została jednomyślnie przyjęta na wniosek ministra WR i OP Karola hr. von Stürgkha na posiedzeniu Rady Państwa (31 X 1911). We wniosku Ministerstwa WR i OP $\mathrm{z}$ dnia $31 \mathrm{X}$ t. r., przedłożonym ces. Franciszkowi Józefowi I w dniu 6 XI 1911 r. ks. A. S. Sapieha był jedynym kandydatem na Kraków. Jego też zamianował cesarz $\mathrm{w}$ dniu 8 listopada t. r. biskupem ordynariuszem krakowskim ${ }^{78}$. W dniu 27 XI t. r. nastąpiła prekonizacja papieska, a w dniu 17 XII t. r. pap. Pius X osobiście konsekrował go na biskupa. W dniu 3 III 1912 r. książę biskup Sapieha odbył uroczysty ingres do katedry wawelskiej. Ingres ten powtórzył w dniu 17 I 1926 r., kiedy pap. Pius XI zamianował go pierwszym metropolitą krakowskim, a biskup tar-nowski Leon Wałęga włożył nań paliusz arcybiskupi. Pontyfikat ks. Sapiehy rozpoczęty w $1911 \mathrm{r}$. i ozdobiony purpurą kardynalską przez pap. Piusa XII (18 II 1946) trwal do 23 VII 1951 r. jako jeden z najwspanialszych w episkopacie polskim XX stulecia.

77 Tamże, $370 \mathrm{n}$.

78 Zob. przyp. 67 - Ich ernenne den Domherrn des römisch-katholischen Metropolitankapitels in Lemberg Adam Fürsten Sapieha zum Fürstbischofe von Krakau 8 XI 1911.

DE PRAESENTATIONE NOMINATIONEQUE EPISCOPORUM CRACOVIENSIUM IN ANNIS 1790-1914

\section{A R G U M E N T U M}

Inde ab anno 1790 usque ad 1914 urbs et dioecesis Cracoviensis quaternis vicibus politicam suam depententiam mutavere, nam ad annum ultimae dispartitionis Poloniae (1795) intra fines reipublicae Polonae eas existere, nemo est qui ignoret. Unde etiam regibus Poloniae vi antiquissimae consuetudinis, a Romanis pontificibus iam XVI saeculo confirmae, ius non tam nominandi, quam praesentandi veriusque postulandi episcopos urbis Cracoviae competere, satis notum est. Ultimum antistitem Cracoviensem ab ultimo rege Poloniae Stanislao Augusto Poniatowski Felicem Paulum Turski (1790-1800) postulatum esse agnovimus.

Independentia Poloniae a vicinis imperiis devorata, urbs et dioecesis Cracoviensis annorum 1795-1809 serie imperio Austriae in civilibus subiectas fuisse scimus. Hinc etiam factum est, ut imperator Austriae Franciscus eius nominis I, a Sede Apostolica nova circumscriptione dioecesis obtenta, reformationeque regiminis ac administrationis illius peracta, Andream Gawroński cancellarium capituli eiusdem dioecesis ad episcopatum Cracoviensem nominavit promovitque (1804-1813). Nominationem istam, non tam hereditario, quasi regum Poloniae successore, verius usurpativo modo imperatorem Austriae perfecisse oportet dicere. 
Vi bullae pontificiae, quae a verbis Ex imposita nobis (30 V 1818) perampla olim dioecesis Cracoviensis tantum territorium Liberae et strictissimae Neutralis Civitatis eiusdemque nominis palatinatus in Regno Poloniae consistentem obtinuit. Talium ideoque territorii dioecesis finium respectu congressus politicus, Vindobonensis nuncupatus, iura praesentationis patronatusque erga episcopatum Cracoviensem imperatoribus Russiae adiudicavit, etsi ea a Romanis antistitibus numquam fuere agnita, luculentissime compertum est. Eo iure suffulti imperatores Alexander I - Ioannem Paulum Woronicz (1815-1828), Nicolaus vero I — Carolum Skórkowski (1829-1851) in solium episcopale Cracoviense evehere nominareque.

Insurrectione Novembriana a gubernio Russico crudeliter suffocata, eaque de causa antistite Carolo Skórkowski in exilio Opaviae in Silesia Austriaca manere coacto, utriusque pars dioecesseos, Kielciis pro territorio Russico in sic dicto Regno Poloniae, Cracoviae vero pro anteacto territorio Liberae Civitatis, nunc vero in civilibus imperio Austriaco subiecto, singulares cum plena iurisdictione vicarios apostolicos Sedes Apostolica, a superius imperiis denominatis compulsa, nominavit constituitque.

Anno 1880 dioecesis Cracoviensis novum te̊rritorium ad ripam dexteram Vistulae sortitam esse optime scimus; imperator vero Austriae, vi privilegii pontificii, Franciscus Josephus eius nominis I, tribus vicibus in serie Albinum Dunajewski (18791894), Ioannem principem de Kozielsko Puzyna (1894-1911), Adamumque Stephanum principem Sapieha $(1911-1951)$ in pastores antistitesque cathedralis ecclesiae s. Venceslai Cracoviae et praesentavit nominavitque, adiecto titulo principis. Hii omnes tres in ordine suo tempore a Romanis pontificibus cardinales creati fuere, Polonorum genti plenissime patet. 